\title{
Milk progesterone on day 5 following insemination in the dairy cow: associated metabolic variables and reproductive consequences
}

\author{
L. Y. Yan ${ }^{1}$, R. S. Robinson ${ }^{2}$, Z. D. Shi ${ }^{1 \#}$ \& G. E. Mann ${ }^{3 \#}$ \\ ${ }^{1}$ Institute of Animal Science, Jiangsu Academy of Agricultural Sciences, Nanjing 210014, P.R. China \\ ${ }^{2}$ School of Veterinary Medicine and Science, University of Nottingham, Sutton Bonington Campus, Loughborough LE12 \\ $5 \mathrm{RD}, \mathrm{UK}$ \\ ${ }^{3}$ Division of Animal Sciences, School of Biosciences, University of Nottingham, Sutton Bonington Campus, \\ Loughborough LE12 5RD, UK
}

(Received 12 October 2016; Accepted 15 September 2017; First published online 1 January 2018)
Copyright resides with the authors in terms of the Creative Commons Attribution 4.0 South African Licence.
See: http://creativecommons.org/licenses/by/4.0/za
Condition of use: The user may copy, distribute, transmit and adapt the work, but must recognise the authors and the South African Journal of Animal Science.

\begin{abstract}
Despite the importance of progesterone on the fertility of lactating dairy cows, the factors that affect post ovulatory progesterone concentration are still unclear. Thus, the aim of the present study was to identify factors associated with the post ovulatory progesterone rise following $1^{\text {st }}$ insemination in lactating dairy cows. Data collected across a number of complimentary studies were compiled to produce a single database of 168 lactating Holstein Friesian dairy cows maintained under commercial conditions. In all animals a number of variables were measured during the insemination period and related to milk progesterone measured on day 5 following $1^{\text {st }}$ artificial insemination (AI). Overall, 44\% of cows conceived to $1^{\text {st }} \mathrm{Al}$ and while mean day 5 progesterone was not significantly higher in these cows, there was a significant quadratic relationship between milk progesterone concentration and conception rate. While a number of variables showed some association with progesterone concentration, the only variable showing a strong and repeatable relationship was plasma leptin concentration. We conclude that adequate but not excessive progesterone levels on day 5 bring about a better fertility, and plasma leptin concentration may be a much better indicator of metabolic status in lactating dairy cows.
\end{abstract}

Keywords: Conception rate, dairy cow, leptin, metabolic variables, milk progesterone

\# Corresponding author: zdshi@jaas.ac.cn, George.mann@nottingham.ac.uk

\section{Introduction}

It is now well established that failure of the corpus luteum to produce sufficient progesterone represents a major cause of early embryo loss and reproductive problems in the modern dairy cow. During early pregnancy, progesterone influences the secretory function of the uterus, including nutrients, growth factors, immunosuppressive agents, enzymes, ions, and steroids that are essential for embryo development (Graham \& Clarke, 1997).

Further studies on the role of progesterone during early pregnancy in the cow have now identified the close link between maternal progesterone concentration after mating and early embryo development (Mann \& Lamming, 2001; Green et al., 2005; Mann et al., 2006; McNeill et al., 2006; Morris \& Diskin, 2008), as well as the outcome of pregnancy (Larson et al., 1997; Starbuck et al., 2001; Hommeida et al., 2004; Bisinotto et al., 2010; Kafi \& Mirzaei, 2010). In both lactating (Starbuck et al., 2001) and non-lactating dairy cows (Mann \& Lamming, 2001), a poor post-ovulatory rise in progesterone, and more specifically, poor progesterone concentrations on day 5 after mating, has been associated with poor embryo development and low pregnancy rates. Stronge et al. (2005) found a linear and quadratic relationship between the concentration of milk progesterone on days 5 - 7 following insemination and also between the rate of increase in progesterone between days 4 and 7 and embryo survival. Green et al. (2005) demonstrated that embryo developmental capacity of dairy cows is closely related to both plasma and luteal progesterone concentrations as early as day 5 post-Al. McNeill et al. (2006) also found a similar linear and quadratic relationship between the concentration of milk progesterone and embryo survival on days 4 to 6 after ovulation and embryo survival, and progesterone 
concentration on days 4 and 5 were highly predictive of concentrations on days 7 and 6 , respectively. This provides evidence that progesterone production is key to the success of early pregnancy in the dairy cow and milk progesterone concentration on day 5 following mating can be used to monitor reproductive function during the post-partum period. Despite the importance of progesterone, many questions remain unanswered surrounding the way in which level of progesterone secretion is controlled during this important time. Studies using milk progesterone analysis to monitor luteal activity have suggested associations between factors such as milk yield and body condition score (BCS) and progesterone concentrations (Mann et al., 2005; BechSa'bat et al., 2008). However, the mechanisms regulating post-ovulatory progesterone concentration are complex and require further study. Therefore, in the present study, we have investigated the relationship between milk progesterone on day 5 following insemination and a variety of metabolic variables as well as measures of reproductive performance in lactating dairy cows.

\section{Material and Methods}

Data from a total of 8 groups of cows spread across 6 herds investigating the relationships between metabolic parameters and reproductive performance in Holstein-Friesian dairy cows in the UK were collated into a single dataset of 168 cows. The cows were spring calving and multiparous, parity ranged from 2 to 6 and were randomly assigned to each group. In all studies, no experimental treatments had been imposed on the animals which were all lactating Holstein Friesian cows maintained within a range of commercial herd environments. Cows were fed various diets comprising a total mixed ration based on grass and maize silage with additional feedstuffs as well as concentrates fed according to yield. Daily feed allowances were adjusted for each cow to at least $110 \%$ of intake, to ensure ad libitum feeding. All work was conducted under the Animals (Scientific Procedures) Act 1986 with local ethical approval.

Depending on the study, blood samples were collected by venipuncture into heparinised tubes at various 1 to 4 week intervals during the post-partum period and kept on ice until centrifuged and plasma harvested and stored at $-20{ }^{\circ} \mathrm{C}$. In the present study, a mean value was determined for each parameter from samples collected between weeks 7 and 15 post-partum (the time period during which 1st Al occurred). In addition, animals were condition scored (on a 1 - 5 scale) and milk yield recorded at various time-points post-partum. Once again, a mean value was determined for each animal based on those measurements made between weeks 7 and 15 post-partum. Cows were artificially inseminated at observed oestrus according to routine farm practice with semen from bulls selected by the farm following a voluntary waiting period of around 7 weeks. In all animals, a milk sample was collected on day 5 following oestrus (day 0 ) associated with 1st insemination with cows inseminated on the day of oestrus or the following morning.

All samples were analysed for leptin by radioimmunoassay as described by Blache et al. (2000) with inter- and intra-assay coefficients of variation of 13.1 and $8.5 \%$ respectively and a sensitivity of $0.2 \mathrm{ng} / \mathrm{ml}$. Milk progesterone was measured by radioimmunoassay (Lamming \& Bulman, 1976) with a sensitivity of 1 $\mathrm{ng} / \mathrm{ml}$ and intra- and inter-assay coefficients of variation of 11.3 and $14.2 \%$, respectively. These two analyses were compared and show no differences in the determination of progesterone concentrations of the same samples. In Groups 1 to 4, plasma concentrations of urea were measured by an enzymatic glutamate dehydrogenase method (Randox Laboratories Ltd, Crumlin, Co. Antrim, UK) with an inter-assay coefficient of variation of $10.5 \%$. Plasma concentrations of $\beta$-hydroxybutyrate (BHB) were measured using a commercially available ( $\beta$-hydroxybutyrate procedure 310-UV, Sigma Diagnostics, Fancy Road, Poole, Dorset, UK) with an inter-assay coefficient of variation of $4.8 \%$. In studies $5-8$, plasma BHB and urea concentrations were measured on an OPERA (Operationally Enhanced Random Access) analyser (Bayer, Newbury, Berks, UK) using kinetic enzymatic kits (Randox Laboratories Ltd, Co. Antrim, UK). Assay sensitivity was $0.1 \mathrm{mmol} / \mathrm{l}$ for both methodologies.

All statistical analyses were performed using GenStat Version 15.0 (VSN international, UK). A summary of variables across the 8 groups of experimental animals is shown in Table 1 with data expressed as mean \pm SEM. In all analyses Group was included as a main factor to ensure that any differences between animal Groups were fully accounted for in the analytical model. Relationships between variables were determined by linear regression analysis, while logistic regression was used to evaluate the relationship between each variables and subsequent conception. For the relationship between conception rate and milk progesterone concentration, further analysis was performed with milk progesterone categorised into incremental $3 \mathrm{ng} / \mathrm{ml}$ concentration intervals $(<3 ; 3-6 ; 6-9 ; 9-12 ; 12-15 ;>15 \mathrm{ng} / \mathrm{ml})$ to fully assess the quadratic regression relationship, as Starbuck et al. (2001) who reported increased embryo survival at progesterone concentration above $3 \mathrm{ng} / \mathrm{ml}$, declining at concentrations greater than $9 \mathrm{ng} / \mathrm{ml}$. Generalized Linear Models (GLM) regression analysis (accumulated analysis) was used to evaluate the factors that affected milk progesterone secretion. 
Table 1 Mean $( \pm$ SEM) concentrations for the variables measured in the 8 groups of lactating Holstein Friesian dairy cows used in the current study

\begin{tabular}{lcccccccc}
\hline Variable & $\begin{array}{c}\text { Group 1 } \\
(\mathbf{n}=\mathbf{1 3})\end{array}$ & $\begin{array}{c}\text { Group 2 } \\
(\mathbf{n}=\mathbf{1 9})\end{array}$ & $\begin{array}{c}\text { Group 3 } \\
(\mathbf{n}=\mathbf{2 7})\end{array}$ & $\begin{array}{c}\text { Group 4 } \\
(\mathbf{n}=\mathbf{3 7})\end{array}$ & $\begin{array}{c}\text { Group 5 } \\
(\mathbf{n}=\mathbf{4 6})\end{array}$ & $\begin{array}{c}\text { Group 6 } \\
(\mathbf{n}=\mathbf{5})\end{array}$ & $\begin{array}{c}\text { Group 7 } \\
(\mathbf{n}=\mathbf{8})\end{array}$ & $\begin{array}{c}\text { Group 8 } \\
(\mathbf{n}=\mathbf{1 3})\end{array}$ \\
\hline $\begin{array}{l}\text { Conception } \\
(\%)\end{array}$ & 69.2 & 10.5 & 63.0 & 56.8 & 32.6 & 60.0 & 25.0 & 38.5 \\
$\begin{array}{l}\text { Day 5 MP4 } \\
(\mathrm{ng} / \mathrm{ml})\end{array}$ & $7.8 \pm 1.62$ & $5.5 \pm 0.54$ & $5.4 \pm 0.48$ & $10.6 \pm 0.88$ & $9.4 \pm 0.69$ & $12.9 \pm 1.72$ & $11.2 \pm 1.84$ & $5.7 \pm 0.97$ \\
$\begin{array}{l}\text { Day of } \\
1_{\text {stAl }} \text { Al }\end{array}$ & $64.5 \pm 5.08$ & $62.4 \pm 3.51$ & $65.6 \pm 3.95$ & $80.4 \pm 3.12$ & $89.2 \pm 3.45$ & $54.4 \pm 3.59$ & $61.5 \pm 7.33$ & $65.6 \pm 5.33$ \\
$\begin{array}{l}\text { Milk yield } \\
\text { (I/d) }\end{array}$ & $37.7 \pm 1.68$ & $39.3 \pm 1.60$ & $29.7 \pm 1.27$ & $37.1 \pm 0.99$ & $36.3 \pm 1.39$ & $33.4 \pm 3.24$ & $32.8 \pm 1.21$ & $27.5 \pm 1.49$ \\
$\begin{array}{l}\text { Condition } \\
\text { score }\end{array}$ & $1.6 \pm 0.19$ & $1.2 \pm 0.15$ & $2.1 \pm 0.15$ & $1.7 \pm 0.18$ & $1.8 \pm 0.15$ & $1.8 \pm 0.69$ & $1.1 \pm 0.22$ & $2.4 \pm 0.47$ \\
$\begin{array}{l}\text { Plasma leptin } \\
\text { (ng/ml) }\end{array}$ & $1.7 \pm 0.19$ & $1.2 \pm 0.15$ & $3.5 \pm 0.35$ & $1.7 \pm 0.18$ & $1.8 \pm 0.15$ & $1.8 \pm 0.69$ & $1.1 \pm 0.22$ & $2.4 \pm 0.47$ \\
$\begin{array}{l}\text { Plasma BHB } \\
\text { (mmol/l) }\end{array}$ & $0.6 \pm 0.05$ & $0.9 \pm 0.06$ & $0.7 \pm 0.05$ & $0.7 \pm 0.03$ & $0.6 \pm 0.05$ & $0.5 \pm 0.04$ & $0.6 \pm 0.05$ & $0.6 \pm 0.03$ \\
$\begin{array}{l}\text { Plasma urea } \\
\text { (mmol/l) }\end{array}$ & $6.6 \pm 0.43$ & $5.8 \pm 0.19$ & $5.7 \pm 0.19$ & $6.3 \pm 0.19$ & $7.4 \pm 0.27$ & $7.10 \pm 0.47$ & $3.9 \pm 0.47$ & $5.4 \pm 0.38$ \\
\hline
\end{tabular}

MP4: milk progesterone; Al: artificial insemination; BHB: $\beta$-hydroxybutyrate

\section{Results}

Mean \pm SEM milk progesterone concentration on Day 5, milk yield, body condition score, days of first $\mathrm{Al}$, plasma leptin, plasma BHB and plasma urea in cows that conceived to $\mathrm{Al}(\mathrm{n}=74)$ or did not conceive $(\mathrm{n}$ $=94$ ) are shown in Table 2. Logistic regression analysis revealed no significant effect of any variable on conception rate, though milk progesterone concentration tended to have an influence $(P<0.07)$.

Table 2 Mean ( \pm SEM) milk progesterone (MP4), milk yield, body condition score $(B C S)$, days of $1^{\text {st }} \mathrm{Al}$ and plasma concentrations of metabolites in pregnant and non-pregnant cows

\begin{tabular}{lccc}
\hline Parameters & $\begin{array}{c}\text { Pregnant } \\
(\mathbf{n}=\mathbf{7 4})\end{array}$ & $\begin{array}{c}\text { Non-pregnant } \\
(\mathbf{n}=\mathbf{9 4})\end{array}$ & Significance \\
\hline Day 5 MP4 $(\mathrm{ng} / \mathrm{ml})$ & $9.1 \pm 0.53$ & $7.7 \pm 0.52$ & 0.07 \\
Days of $1^{\text {st }} \mathrm{Al}$ & $74.8 \pm 2.43$ & $73.9 \pm 2.49$ & $\mathrm{~ns}$ \\
Milk yield $(\mathrm{l} / \mathrm{d})$ & $34.2 \pm 0.93$ & $35.5 \pm 0.82$ & $\mathrm{~ns}$ \\
Body condition score & $1.9 \pm 0.05$ & $1.9 \pm 0.05$ & $\mathrm{~ns}$ \\
Plasma leptin $(\mathrm{ng} / \mathrm{ml})$ & $2.2 \pm 0.18$ & $1.8 \pm 0.13$ & $\mathrm{~ns}$ \\
Plasma BHB $(\mathrm{mmol} / \mathrm{l})$ & $0.7 \pm 0.04$ & $0.7 \pm 0.02$ & $\mathrm{~ns}$ \\
Plasma urea $(\mathrm{mmo} / \mathrm{l})$ & $6.2 \pm 0.17$ & $6.5 \pm 0.18$ & $\mathrm{~ns}$
\end{tabular}

ns: mean value within a row did not differ significantly; MP4: milk progesterone; Al: artificial insemination; BHB: $\beta$ hydroxybutyrate

However, further analysis of the relationship between milk progesterone concentration on day 5 and the outcome of insemination revealed a significant $(P<0.001)$ quadratic relationship with both low $(<3 \mathrm{ng} / \mathrm{ml}$ and $3-6 \mathrm{ng} / \mathrm{ml})$ and high progesterone $(>12 \mathrm{ng} / \mathrm{ml})$ concentrations associated with reduced conception rates (Figure 1). The proportion of cows with a day 5 milk progesterone concentration of $<3 \mathrm{ng} / \mathrm{ml}$ was $10.7 \%$. 


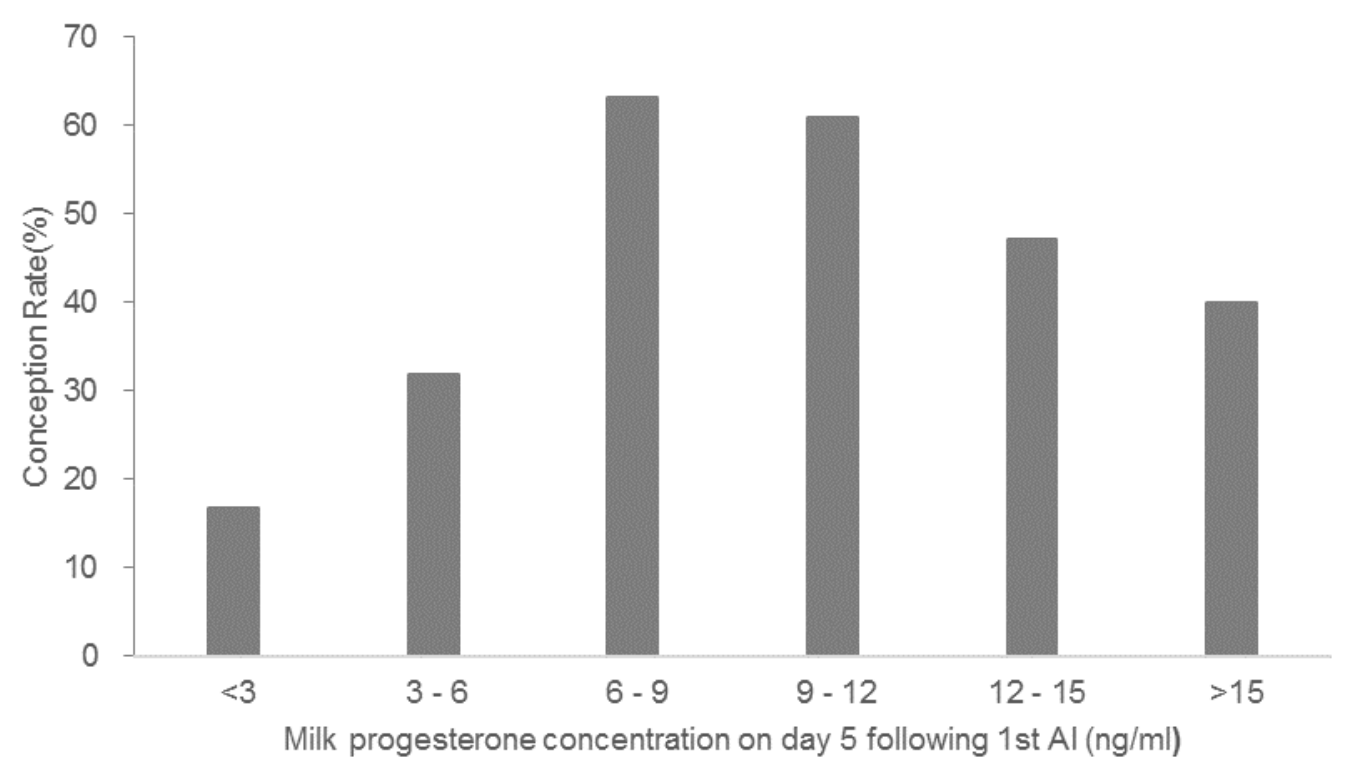

Quadratic regression revealed a significant $(P<0.001)$ relationship between milk progesterone and conception rate.

Figure 1 The relationship between milk progesterone concentration $(\mathrm{ng} / \mathrm{ml}) 0$ on day 5 following first insemination and conception rate in lactating Holstein Friesian cows.

The relationships between milk progesterone, milk yield, BCS, days of 1 st AI, plasma leptin, plasma BHB and plasma urea are shown in Table 3. Concentration of milk progesterone on Day 5 after mating was positively associated with body condition score $(P<0.05)$ and days of first $\mathrm{Al}(P<0.05)$ and negatively associated with plasma BHB $(P<0.05)$, plasma leptin $(P<0.07)$. Plasma leptin had a significant positive relationship $(P<0.05)$ with body condition score and negative relationship with milk yield $(P<0.01)$. Milk yield showed a significant negative association with BCS $(P<0.05)$. There was also negative correlation between plasma urea concentration and days of first $\mathrm{Al}(P<0.05)$. Contrary to expectations, there was no relationship whatsoever between milk yield and progesterone concentration (Figure 2).

Table 3 The correlation coefficients between milk progesterone, milk yield, body condition score, days of $1^{\text {st }}$ artificial insemination and plasma concentrations of metabolites

\begin{tabular}{|c|c|c|c|c|c|c|}
\hline Parameters & MP4 & Leptin & Milk yield & BCS & Al Day & BHB \\
\hline Leptin & 0.144 & & & & & \\
\hline Milk yield & -0.045 & $0.286^{\star *}$ & & & & \\
\hline BCS & 0.185 & $0.235^{\star *}$ & $-0.211^{* *}$ & & & \\
\hline Al Day & $0.169^{*}$ & -0.051 & 0.034 & 0.103 & & \\
\hline BHB & $-0.173^{\star}$ & -0.060 & 0.048 & -0.146 & 0.057 & \\
\hline Urea & 0.109 & 0.018 & $0.159^{*}$ & 0.133 & $0.172^{*}$ & -0.053 \\
\hline
\end{tabular}




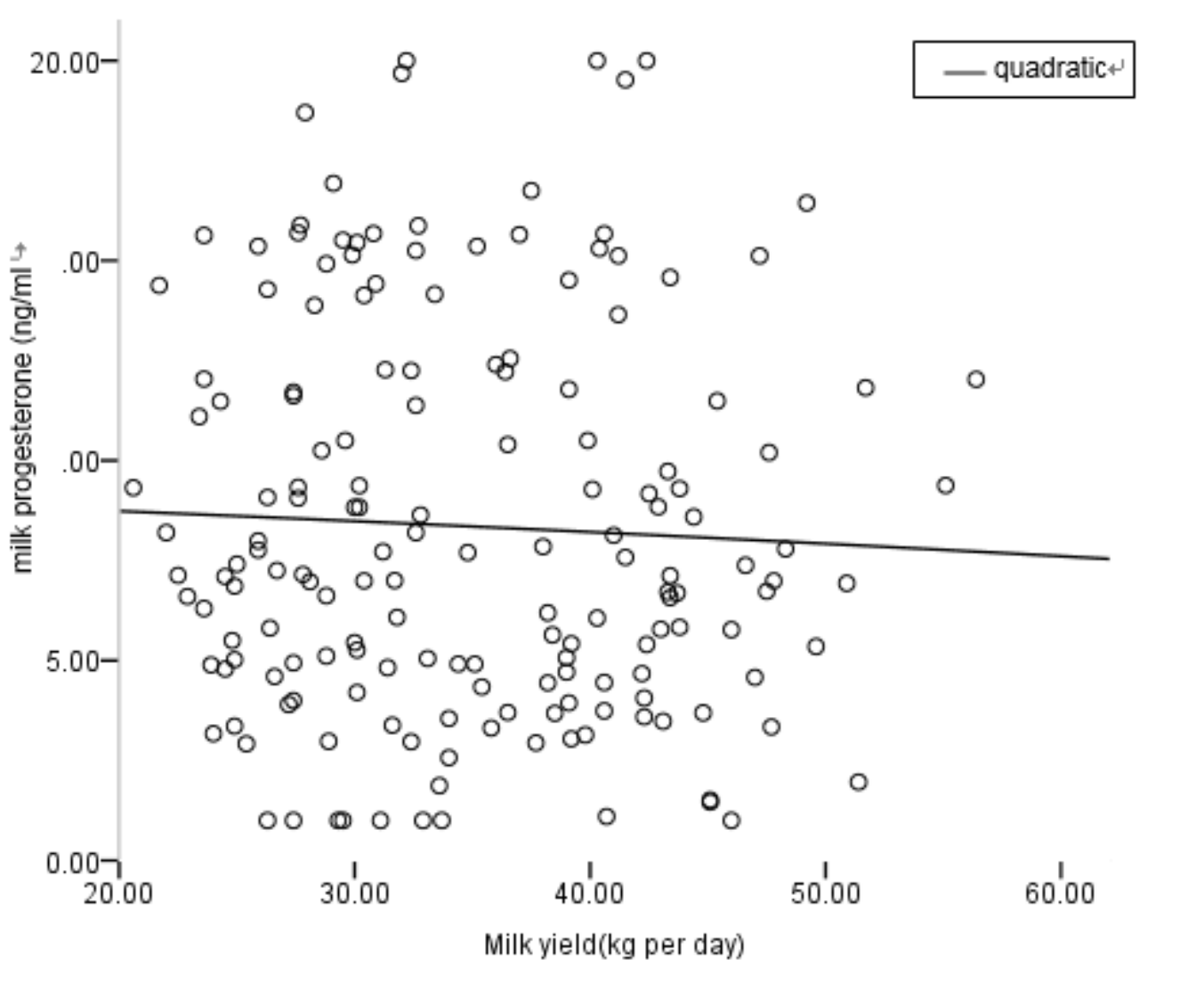

Figure 2 Quadratic relationship between milk yield (kg per day) and the concentration of progesterone $(\mathrm{ng} / \mathrm{ml})$ in milk samples collected on day 5 following first insemination in Holstein Friesian cows

The outcomes of multiple linear regression analysis of the effect of the variables measured on day 5 milk progesterone are shown in Table 4. There was a significant influence of both group $(P<0.001)$ and plasma leptin concentration $(P<0.001)$ on milk progesterone concentration. All the other variables had no significant influence on milk progesterone concentration.

Table 4 Accumulated regression analysis of factors affects milk progesterone production

\begin{tabular}{lc}
\hline Parameters & Significance $\boldsymbol{P}$ \\
\hline Group & $<.001$ \\
Plasma leptin $(\mathrm{ng} / \mathrm{ml})$ & $<.001$ \\
Body condition score & 0.169 \\
Milk yield $(/ \mathrm{d})$ & 0.144 \\
Plasma BHB $(\mathrm{mmol} / \mathrm{l})$ & 0.233 \\
Days of $1^{\text {st }} \mathrm{Al}$ & 0.324 \\
Plasma urea $(\mathrm{mmol} / \mathrm{l})$ & 0.928 \\
\hline
\end{tabular}

Al: artificial insemination; BHB: $\beta$-hydroxybutyrate

\section{Discussion}

Progesterone (P4) is considered the gold standard for evaluation of the reproduction status for research purposes (Adriaens et al., 2017). A number of studies in dairy cows have reported an association 
between insufficient maternal progesterone production during the early pregnancy period and early embryo loss (Larson et al., 1997; Mann \& Lamming, 2001; Starbuck et al. 2001; Hommeida et al., 2004; Green et al., 2005; Mann et al., 2006; McNeil et al., 2006). Progesterone concentrations on 5-10 days after insemination were higher in pregnant than non-pregnant cows in some studies (Hansel, 1981; Fonseca et al., 1983; Lamming et al., 1989; Larson et al., 1997; Hommeida et al., 2004), but not in others (Sreenan \& Diskin, 1983; Nosier et al., 1992; Green et al., 2005). In the current study, the overall mean milk progesterone levels in pregnant cows did not differ significantly from non-pregnant cows $(P<0.07)$ but there was a strong quadratic relationship with both low and high milk progesterone concentrations associated with reduced conception rates. Thus it would appear that, as well as inadequate progesterone levels, excessive progesterone levels on day 5 also present a problem. Whether these high progesterone concentrations are the result of premature development of luteal function leading to embryo-uterus asynchrony or simply reflect mistimed inseminations remains to be determined. Within the parameters of the present study, milk progesterone concentration between $6-12 \mathrm{ng} / \mathrm{ml}$ on Day 5 was consistent with maximal conception rate with lower or higher concentrations resulting in reduced conception rate. Similar trends in the relationship between progesterone and fertility were observed in other studies. For example, Starbuck et al. (2001) reported maximum conception rates at day 5 milk progesterone concentrations of $7-8 \mathrm{ng} / \mathrm{ml}$ while Stronge et al. (2005) similarly reported that maximal embryo survival with milk progesterone concentration of $7.4 \mathrm{ng} / \mathrm{ml}$ on Day 5. Cows with subnormal progesterone concentrations have a stronger luteolytic signal, which might predispose to a higher incidence of embryo loss (Mann \& Lamming, 1995).

In an attempt to identify factors that affect milk progesterone concentrations, we found that plasma leptin has the most important influence on the milk progesterone concentration in dairy cows on Day 5 after mating. Previously, leptin has been shown to affect ovarian function in the cow and has been shown to have direct effects on both granulosa and theca cell function (Spicer, 2001). Nicklin et al. (2007) also reported the expression of leptin receptors at all stages of bovine CL, suggested that the bovine ovary is a target for leptin action, but leptin only stimulated progesterone production in the presence of IGF-1 in cultured luteal explants. Whether the association with leptin results from direct effects on the ovary or through other factors needs further study. Leptin concentrations reflect body fat levels and so higher leptin levels may reflect higher body fat reserves which could be associated with better energy status and better reproductive function. In the present study, plasma leptin showed a moderate correlation with body condition score, it was similar to other reports in dairy cows (Ehrhardt et al., 2000; Mann et al., 2005). In the past, body condition score has been used as a subjective method to assess body composition and energy balance status of dairy cattle (Dechow et al., 2001; Dechow et al., 2002; Pryce et al., 2001; Veerkamp et al., 2001). Cows that went through a period of net energy balance postpartum displayed significantly lower progesterone concentrations (VillaGodoy et al.,1988; Sartori et al., 2004). This implies that net energy balance inhibited luteal capability for secreting progesterone, or a higher rate of metabolization in the liver of lactating cows. The significant influence of leptin on milk progesterone secretion and its correlation with BCS suggests that leptin concentration is a much better indicator of body fatness or metabolic status in lactating dairy cows.

A number of studies have reported lower progesterone concentrations in higher yielding cows and suggested increased metabolic clearance of progesterone as the principle cause of luteal inadequacy (Lopez et al., 2005; Wiltbank et al., 2014). However, in the present study, we found no relationship whatsoever between milk yield and the concentration of progesterone during a critical period of early pregnancy. It may due to the low number of animals or the variation between cows. Consequently, it is required that greater numbers of animals should be used in future experiments to draw conclusions.

\section{Conclusion}

While there was not an overall significant difference in milk progesterone concentration between those cows that conceived and those that failed to conceive there was a strong quadratic relationship with both low and high milk progesterone associated with reduced conception. The key variable associated with milk progesterone concentration appeared to be the plasma concentration of leptin with milk yield, contrary to expectations, demonstrating no relationship whatsoever.

\section{Acknowledgements}

The authors are grateful to all the farm staff who contributed to this study and to staff at the Royal Veterinary College for performing some of the assays. The work was funded by the Milk Development Council, DEFRA and the National Science Foundation of China (31601943).

\section{Authors' Contributions}

LY Yan collected the data and drafted the manuscript. RS Robinson performed the statistical analysis. GE Mann designed the study and helped to draft the manuscript. ZD Shi participated in the design of the study. All authors read and approved the final manuscript. 


\section{Conflict of Interest Declaration}

The authors confirm that they have no conflicts of interest to declare.

\section{References}

Adriaens I., Huybrechts, T., Geerinckx, K., Daems, D., Lammertyn, J., De Ketelaere, B., Saeys, W. \& Aernouts, B., 2017. Mathematical characterization of the milk progesterone profile as a leg up to individualized monitoring of reproduction status in dairy cows. Theriogenology 103, 44-51.

Bech-Sa 'bat, G., Lo'pez-Gatius, F., Ya'niz, J.L., Garcı'a-Ispierto, I., Santolaria, P., Serrano, B., Sulon, J., de Sousa, N.M \& Beckers, J.F., 2008. Factors affecting plasma progesterone in the early fetal period in high producing dairy cows. Theriogenology 69, 426-432.

Bisinotto, R.S., Chebel, R.C. \& Santos, J.E., 2010. Follicular wave of the ovulatory follicle and not cyclic status influences fertility of dairy cows. J. Dairy Sci. 93, 3578-3587.

Blache, D., Tellam R.L., Chagas L.M., Blackberry M.A., Vercoe P.E. \& Martin, G.B., 2000. Level of nutrition affects leptin concentrations in plasma and cerebrospinal fluid in sheep. J. Endocrinol. 165, 625- 637.

Bulman, D.C. \& Lamming, G.E., 1978. Milk progesterone levels in relation to conception, repeat breeding and factors influencing acyclicity in dairy cows. J. Reprod. Fertil. 54, 447-458.

Dechow, C.D., Rogers, G.W. \& Clay, J.S., 2001. Heritabilities and correlations among body condition scores, production traits, and reproductive performance. J. Dairy Sci. 84, 266-275.

Dechow, C.D., Rogers, G.W. \& Clay, J.S., 2002. Heritability and correlations among body condition score loss, body condition score, production and reproductive performance. J. Dairy Sci. 85, 3062-3070.

Ehrhardt, R.A., Slepetis, R.M., Siegal-Willott, J., Van Amburgh, M.E., Bell, A.W. \& Boisclair, Y.R., 2000. Development of a specific radioimmunoassay to measure physiological changes of circulating leptin in cattle and sheep. J. Endocrinol. 166, 519-528.

Fonseca, F.A., Britt, J.H., McDaniel, B.T., Wilk, J.C. \& Bakes, A.H., 1983. Reproductive traits of Holsteins and Jerseys. Effect of age, milk yield, clinical abnormalities on involution of cervix and uterus, ovulation, estrous cycles, detection of estrus, conception rate and days open. J. Dairy Sci. 66, 1128-1147.

Graham, J.D. \& Clarke, L.L., 1997. Physiological action of progesterone in target tissue. Endocr. Rev. 18, 502-519.

Green, M.P., Hunter, M.G. \& Mann, G.E., 2005. Relationships between maternal hormone secretion and embryo development on day 5 of pregnancy in dairy cows. Anim. Reprod. Sci. 88, 179-189.

Hansel, W., 1981. Plasma hormone concentrations associated with early embryo mortality in heifers. J. Reprod. Fertill. 30 (Suppl), 231-239.

Hommeida, A., Nakao, T. \& Kubota, H., 2004. Luteal function and conception in lactating cows and some factors influencing luteal function after first insemination. Theriogenology 62, 217-225.

Kafi M. \& Mirzaei A., 2010. Effects of first postpartum progesterone rise, metabolites, milk yield, and body condition score on the subsequent ovarian activity and fertility in lactating Holstein dairy cows. Trop. Anim. Health Prod. 42, 761 767.

Lamming, G.E. \& Bulman, D.C., 1976. The use of milk progesterone radioimmunoassay in the diagnosis and treatment of subfertility in dairy cows. Br. Vet. J. 132, 507-517.

Lamming, G.E., Darwash, A.O. \& Back, H.L., 1989. Corpus luteum function in dairy cows and embryo mortality. J. Reprod. Fertil. 37 (Suppl), 245-252.

Larson, S.F., Butler, W.R. \& Currie, W.B., 1997. Reduced fertility associated with low progesterone postbreeding and increased milk urea Nitrogen in lactating cows. J. Dairy Sci. 80, 1288-1295.

Lopez, H., Caraviello, D.Z., Satter, L.D., Fricke, P.M. \& Wiltbank, M.C., 2005. Relationship between level of milk production and multiple ovulations in lactating dairy cows. J. Dairy Sci. 88, 2783-2793.

Mann, G.E., Fray, M.D. \& Lamming, G.E., 2006. Effects of time of progesterone supplementation on embryo development and interferon-t production in the cow. Vet. Journal 171, 500-503.

Mann, G.E. \& Lamming, G.E., 1995. Progesterone inhibition of the development of the luteolytic signal in cows. J. Reprod. Fertil. 104, 1-5.

Mann, G.E. \& Lamming, G.E., 2001. Relationship between the maternal endocrine environment, early embryo development and the inhibition of the luteolytic mechanism in the cow. Reproduction 121,175-180.

Mann, G.E., Mann, S.J., Blache, D. \& Webb, R., 2005. Metabolic variables and plasma leptin concentrations in dairy cows exhibiting reproductive cycle abnormalities identified through milk progesterone monitoring during the post partum period. Anim. Reprod. Sci. 88,191-202.

McNeill, R.E., Diskin, M.G., Sreenan, J.M. \& Morris, D.G., 2006. Associations between milk progesterone concentration on different days and with embryo survival during the early luteal phase in dairy cows Theriogenology 65, 14351441.

Morris D. \& Diskin M., 2008. Effect of progesterone on embryo survival. Animal 2(8), 1112-1119.

Nicklin, L.T., Robinson, R.S., Marstes, P., Campbell, B.K., Mann, G.E. \& Hunter, M.G., 2007. Leptin in the bovine corpus luteum: receptor expression and effects on progesterone production. Mol. Repro. Dev. 74, 724-729.

Nosier, M.B., Gyawu, P. \& Pope, G.S., 1992. Progesterone concentration in defatted milk in dairy cows in early pregnancy. Br. Vet. J. 148, 45-53.

Pryce, J.E., Coffey M.P. \& Simm G., 2001. The relationship between body condition score and reproductive performance. J. Dairy Sci. 84, 1508-1515.

Sartori R., Haughian, J.M., Shaver, R.D., Rosa, G.J.M. \& Wiltbank, M.C., 2004. Comparison of ovarian function and circulating steroids in estrous cycles of Holstein heifers and lactating cows. J. Dairy Sci.87, 905-920.

Spicer, L.J., 2001. Leptin: a possible metabolic signal affecting reproduction. Domest. Anim. Endocrinol. 21, $251-270$. 
Sreenan, J.M., Diskin, M.G., 1983. Early embryonic mortality in the cow: its relationship with progesterone concentration. Vet. Rec. 112, 517-521.

Starbuck, G.R., Darwash, A.O., Mann, G.E. \& Lamming, G.E., 2001. The detection and treatment of post-insemination progesterone insufficiency in dairy cows. Fertility in the high producing dairy cow, Brit. Soc. Anim. Sci. Occasional. Publication (26), 447-450.

Stronge, A.J.H., Sreenan, J.M., Diskin, M.G., Mee, J.F., Kenny, D.A. \& Morris, D.G., 2005. Post-insemination milk progesterone concentration and embryo survival in dairy cows. Theriogenology 64, 1212-1224.

Veerkamp, R.F., Koenen, E.P.C. \& De Jong, G., 2001. Genetic correlations among body condition score, yield, and fertility in first-parity cows estimated by random regression models. J. Dairy Sci. 84, 2327-2335.

Villa-Godoy, A., Hughes, T.L., Emery, R.S., Chapin, L.T. \& Fogwell, R.L., 1988. Association between energy balance and luteal function in lactating dairy cows. J. Dairy Sci. 71,1063-1072.

Wiltbank, M.C., Souza, A.H., Carvalho, P.D., Cunha, A.P., Giordano, J.O., Fricke, P.M., Baez, G.M. \& Diskin, M.G., 2014. Physiological and practical effects of progesterone on reproduction in dairy cattle. Animal 8 (Suppl 1), 70-81. 